УДК 327-053.67/-053.81(497.1:496.5)«1945/1948»

\author{
Slavković Mirić Božica \\ $\mathrm{PhD}$ (Historical Sciences) \\ Research Associate \\ Institute for Recent History of Serbia \\ Trg Nikole Pašića 11, Belgrade, Republic of Serbia \\ e-mail: bozica.slavkovic@gmail.com \\ DOI: http://dx.doi.org/10.18524/2304-1439.2020.33.209092
}

\title{
COOPERATION BETWEEN YUGOSLAV AND ALBANIAN YOUTH 1945-1948
}

\begin{abstract}
Yugoslavia and Albania began cooperation after the Second World War, which intensified after the signing of the Treaty of Friendship in 1946. That cooperation was ideological, political, cultural, medical, military, etc. The crisis in Yugoslav-Albanian relations occurred when the Soviet and Albanian party leadership established direct cooperation, with Enver Hoxha's visit to Moscow in mid-1947. Finally, Yugoslav aid and co-operation were forgotten when the Informbiro resolution was passed and when Albania sided with the USSR. Relations between Yugoslavia and Albania were normalized after 1955. Our research is based on the analysis of archival sources and professional literature, with the help of which we obtained a basis to upgrade the set topic and put it in the context of relations between Yugoslavia and Albania 1945-1948. The paper refers to the youth cooperation between Yugoslavia and Albania. The aim of the paper is to show the intensity of that type of cooperation and what it was reflected in. Youth organizations promoted mutual cooperation and held congresses. Albanian students studied in Yugoslavia, which provided a number of scholarships. Albanian youths were taught in Yugoslav factories. Youth organizations, following the example of the Yugoslav ones, participated in voluntary works in the country and its renewal in that way. An example of Yugoslav-Albanian youth co-operation was the construction of the Durres-Elbasan railway. However, the collapse of Yugoslav-Albanian relations from mid-1947 to the peak of 1948 also affected this aspect of cooperation. Yugoslav and Albanian youth returned to their homes, and youth cooperation was severed.
\end{abstract}

Key words: Albania, Cooperation, Youth, Yugoslavia, Period after the Second World War

\section{Introduction: A brief overview of Yugoslav-Albanian relations 1945-1948}

During the Second World War, relations were established between the Communist Party of Yugoslavia (CPY) and the Communist Party of Albania (CPA), which gained a new dimension after the war's end (Dedijer, 1949, p. 17; Mugoša, 1975; Hoxha, 1982, pp. 135-136). Although it didn't recover quickly ${ }^{1}$, the Yugoslav state began providing assistance to Albania. It consisted of ideological, political, economic, healthcare, military and cultural aid.

${ }^{1}$ For more information, see: Jugoslavija - trideset godina posle oslobođenja $i$ pobede na fašizmom 1945-1975, 1975, p. 27-28; Kidrič, 1960; Mitrović, 1988; Milošević, 2015, pp. 277278; Živković, 1996. 
Yugoslavia and Albania signed two treaties 1945, one in the form of a military alliance for the joint fight against the German occupation forces, which was to be extended in the post-war years, and the other constituting a treaty on economic cooperation between Yugoslavia and Albania (Borozan, 1995, pp. 513-514; Petranović, 1994, p. 97; Selinić \& Bajagić, 2010, p. 46; Smodlaka, 1986, pp. 220-222). ${ }^{1}$

The highlight of the cooperation between Yugoslavia and Albania was Enver Hoxha's ${ }^{2}$ visit to Yugoslavia in mid-1946 (Babić, 1981, p. 68; Zlatar, 1986, p. 112). A treaty on economic co-operation, payments and loans was signed, followed by a Friendship and Assistance Treaty in Tirana (Dedijer, 1949, pp. 152-154). ${ }^{3}$ In November 1946, the Agreement on the Harmonization of Economic Plans, on the Customs Union and on the Equalization of Currencies between the two countries was signed, which was a unique example of regulating economy between two socialist countries (Avramov, 1985, p. 175; Dedijer, 1949 , p. 174). ${ }^{4}$

In spite of the economic improvement of the Albanian state made possible by Yugoslav assistance, mistrust and reservations were evident in the Albanian leadership. That was the reason why the Albanian leader expressed his desire for direct co-operation with the USSR. ${ }^{5}$ The two countries signed the Trade Agreement on 22 June 1947 (Borozan, 1999, p. 50; Dimić, 2010, p. 245; Hoxha, 1979, pp. 55-90; Komatina, 1995, pp. 65-66; Pollo \& Puto, 1974, p. 308; Zlatar, 1986, p. 135; Životić, 2015, pp. 161-162). Decline in relationship between Yugoslavia and Albania was felt in all fields. ${ }^{6}$

The official separation came after the publication of the Informbiro Resolution in June 1948. Albania agreed to this resolution and terminated all treaties with Yugoslavia except the Friendship Treaty, which Yugoslavia terminated on 12 November 1949 (Borozan, 1997, p. 32; Frasheri, 1964, pp. 336-337; Laker, 1999, p. 417; Pipa, 1990, pp. 137-138.). Due to the change in the Albanian attitude towards Yugoslavia, the Government of the Federal People's

\footnotetext{
${ }^{1}$ Archive of Yugoslavia (Hereafter AY), Fund Presidency of the Government of the Federal People's Republic of Yugoslavia (Predsedništvo Vlade FNRJ), 50-48-105, Protokol povodom sklapanja Trgovinskog ugovora, 1 July 1946.

${ }^{2}$ Enver Hodža (Djirokastra, 16 October 1908 - Tirana, 11 April 1985) was the supreme leader of the People's Republic of Albania from the end of World War II until his death, as the first secretary of the Communist Albanian Labor Party. He was also the Prime Minister of Albania from 1944 to 1954 and the Minister of Foreign Affairs from 1946 to 1953 (For more information, see: Adamović, 1987, p. 162-171; Balčevski, 1987; Dervishi, 2012, p. 136; Dervishi, 2016, p. 188; Elsie, 2013, p. 207-208; Fevziu, 2011; Fevziu, 2014; Fowkes, 2000, p. 141; Vasfi, 2012; Vikers, Petifer, 1998, p. 12; Zlatar, 1986).

${ }^{3}$ AY, Fund Tanjug news agency (Novinska agencija Tanjug), 112-796-797, July 1946; AY, 112-801-802, 4 November 1946.

${ }^{4} \mathrm{AY}, 50-48-105$, Ugovor između vlada FNRJ i NRA o usklađivanju privrednih planova, carinskoj uniji i izjednačenju valuta, 27 November 1946.

${ }^{5}$ AY, Fund Commission for International Relations of the Central Committee of the SKJ (Komisija za međunarodne veze CK SKJ), 507/9, 1/1-127-242, Zabeleške iz izveštaja.

${ }^{6}$ AY, 50-48-105, Izveštaj o jugoslovensko-albanskoj privrednoj saradnji, 20 November 1947; Diplomatic Archive of the Ministry of Foreign Affairs of the Republic of Serbia (Belgrade) (Hereafter: DAMFARS) Political Archives (PA), 1947, folder 3, document No. 1, signature 5598, Prikaz unutrašnje političke situacije u Albaniji.
} 
Republic of Yugoslavia suspended the work of the Embassy in Tirana on 4 June 1950, and dealt with the Albanian government through the Embassy in Budapest. Albania suspended its embassy in Belgrade on 22 November of that year (Cvetković, 2012, p. 206). Yugoslavia and Albania reopened their diplomatic offices in Tirana and Belgrade in 1954, but relations between the two countries remained cold and reserved (Borozan, 2005, p. 137; Cvetković, 2013).

\section{Yugoslav-albanian youth cooperation}

After the end of the Second World War, given the progress of relations between Yugoslavia and Albania, youth cooperation between the two countries was established. Youth organizations represented «more or less transmissions of communist parties in power». Thus, the initiative for holding the Balkan Congress of Anti-Fascist Youth was given by the youth of Yugoslavia. From 19 to 22 May 1945, the youth delegations of Yugoslavia, Albania, Bulgaria and Greece worked out a congress platform in Belgrade (Mitrović, 1997, p. 194; Živković, 1980, p. 14). In July 1945, the Congress of Anti-Fascist Youth of the Balkan Countries was held in Belgrade. At that time, 50 delegates and 29 observers came from Albania (100 delegates and 54 observers from Bulgaria, one delegate and 29 observers from Greece, 46 delegates from Romania and 90 delegates and 206 observers from Yugoslavia). On that occasion, Yugoslav president Josip Broz Tito addressed the youth and called on them to cooperate in the fight for peace (Mijalkovic \& Brajović, 1980, pp. 8-9).

With the aim of developing and strengthening ties among young people, the Balkan Youth Council was created. During its existence in Yugoslavia, there were, among others, 11 delegations of Albanian youth with 278 young people. Yugoslav and Albanian youth had a very developed cooperation in the first postwar years. From August 1944 to May 1945, Nijaz Dizdarević was, among other things, an instructor of the Central Committee of the Association of Communist Youth of Yugoslavia (SKOJ) at the Central Committee of the Albanian Communist Youth. Brana Petrović, a member of the Politburo of the Central Committee of the SKOJ, was also sent to Albania to provide assistance in working with the youth. Youth organizations printed brochures in Yugoslavia for the needs of Albanian youth, and cooperated in exhibitions. The Albanian anti-fascist youth organization (BRASH) developed on the model of United Alliance of Anti-Communist Youth of Yugoslavia. Work actions were organized similarly as in Yugoslavia, they exchanged work brigades and delegations (Mitrović, 1997, p. 197). In December 1945, when the United Alliance of Anti-Fascist Youth of Vojvodina held its first congress, in addition to guests from Greece, Bulgaria, Romania and the USSR, there were also representatives of the youth of Albania (Mijalković\&Brajović, 1980, p. 2-3).

The following year, 1946, cooperation between the Yugoslav and Albanian states continued on the issue of youth. This was also shown by the fact, stated by the Yugoslav envoy Josip Đerđa, that «the majority of youth leaders sought 
closer ties and fuller cooperation with Yugoslavia». ${ }^{1}$ Good relations were reflected in the level of Albanian students who studied in Yugoslavia. The Albanian government expressed a desire to send 50 students to Yugoslavia, but since the University of Belgrade was overloaded, they should have gone to the universities of Zagreb and Ljubljana. ${ }^{2}$ In January 1946, the Yugoslav government approved scholarships for 15 Albanian students and wanted to accept an unlimited number of students who would study at their own expense. ${ }^{3}$

Youth organizations in Albania, following the example of the Yugoslav ones, participated in voluntary works in the country and its renewal in that way (Petranović, 1964, p. 19). Albanian youth, in their newspaper Rinia, wrote a lot about the work of youth in Yugoslavia. In the Yugoslav propaganda, it was assessed that BRASH shows great interest in the problems of the Yugoslav youth, that «many things are sometimes and quite consistently transferred to their organization». They used Yugoslav materials abundantly, sent their delegations, and the leaders often came. One hundred Albanian students spent their summers in Slovenia in 1946, while 300 were studying various trades. A brigade of 192 Albanians was on the construction of the Brčko-Banovići railway. A total of 312 young people stayed in Yugoslavia in 1946 (Mitrović, 1997, p. 198). Bashkimi began publishing texts about the voluntary work of the youth, which spread rapidly, so in March 1946, the unions and the youth issued a proclamation for the May Day competition. Albanian youth, in cooperation with the workers, volunteered to rebuild the country. ${ }^{4}$ Work has begun on the construction of the Pishkopeja-Kuks road, with the participation of the Albanian population. This road was $65 \mathrm{~km}$ long. ${ }^{5}$ Through voluntary work, the Štiken canal was built in the vicinity of $\mathrm{Kuks}^{6}$, as well as the Berat-Korovode railway. Burned houses were built, schools were built and canals were dug. ${ }^{7}$ In this way, the Albanian state reportedly «saved in many expenses». ${ }^{8}$

Albanian youth largely supported friendly Yugoslav-Albanian relations. The youth newspaper Rinia wrote: «The economic and cultural development that is being achieved in Yugoslavia and the very good economic and cultural relations we have with our neighbor are the main factors for the development of our young economy, for the progress of our new culture». ${ }^{9}$ During the World Youth Week, Albanian youth visited Yugoslavia and were delighted that «everyone inquired about the development of Albanian youth, about building

\footnotetext{
${ }^{1}$ AY, 507/ 9, box 1, 1/1-44, 9 February 1946.

${ }^{2}$ DAMFARS, PA, fol. 2, 1946, doc. no. 6, sign. 6113 , Albanski studenti na našim univerzitetima, 17 November 1945.

${ }^{3}$ DAMFARS, PA, fol. 2, 1946, doc. No. 6, sign. 350, Prvi regionalni odsek jugoslovenskom poslanstvu, 11 January 1946.

${ }^{4} \mathrm{AY}, 507 / 9$, box 1, 1/1-56, 15 April 1946.

${ }^{5}$ DAMFARS, PA, 1946, doc.no. 21, sign. 5793, Josip Đerđa Ministarstvu inostranih poslova, 20 May 1946.

${ }^{6}$ AY, 112-795-796, 1- 2 June 1946.

${ }^{7}$ AY, 112-799-800, 19 October 1946.

${ }^{8}$ AY, 112-798-799, 17 September 1946.

${ }^{9} \mathrm{AY}, 507 / 9$, 1/3-62, Rinia, 6 March 1946.
} 
the country and similarly". ${ }^{1}$ Upon her return, Liri Belisheva, President of the Main Board of the People's Youth of Albania, expressed her impressions of the Yugoslav state as a "state of prosperity and constant work to improve its own life, without sparing strength and concrete resources to help the vulnerable"; "Works such as the construction of a youth railway can be accomplished with so much success only in a country where the people are in power, where the economy is not in the hands of a few speculators, where the people are free to build their own existence and where the people fight and win. (...) Although they also have to save in order to overcome the difficulties they encounter in their economy, the peoples of Yugoslavia do not hesitate to share their bread and provide assistance to the injured Albanian population. It is not just a campaign for help, it is a noble act that shows the compassion of the Yugoslav people. This gesture proves that the peoples of Yugoslavia consider our misfortune to be their own. This proves that the friendship that binds us is deeply rooted in the hearts of our peoples. (...) The peoples of Yugoslavia help us on all occasions, especially in the economic field, which is of vital importance to us». ${ }^{2}$

After the signing of the Agreement on Friendship and Cooperation, among other things, work was done on sending Albanian youth to training in Yugoslav factories, as well as on admitting Albanian students to Yugoslav faculties. Yugoslav envoy Josip Djerdja demanded a decision from the Yugoslav government on accepting Albania's best young people to learn trades in Yugoslav companies. ${ }^{3}$

By a special protocol from November 1946, the Yugoslav government undertook to receive a number of Albanian youth, in order to train them for leadership and work in the economy. Thus, during 1946 (389), 1947 (188) and 1948 (153), 730 young people came to Yugoslavia who, at the request of the Albanian government, were assigned to vocational schools, technical schools in mining, transport, agriculture or as students in the economy, in the textile, metal, graphic, electrical industry, etc. They were distributed by republics: 284 students were in Serbia, 334 in Croatia, 75 in Slovenia and 37 in Bosnia and Herzegovina. All expenses related to their education were to be borne by the Albanian government, but, according to the Yugoslav report, the obligation to educate them was made by the Yugoslav government with the same conditions as the students in the FPRY. In addition, there were about 450 Albanian students at Yugoslav universities, more than half of whom were Yugoslav government scholarship holders (Petranović, 1988, p.148). ${ }^{4}$ The subsistence of young people in Yugoslavia amounted to about 2,500-3,000 per month per individual, which was a total of 37,500,000, and the Yugoslav Ministry of Labor paid 51,500,000 dinars for various expenses related to the reception and accommodation of young people. ${ }^{5}$

\footnotetext{
${ }^{1}$ AY, 507/9, 1/3-62, Rinia, 10 April 1946.

${ }^{2}$ AY, 507/9, 1/3-63, Tanjug, 5 December 1946.

${ }^{3}$ DAMFARS, PA, fol. 2, 1946, doc.no 2, sign. 6206, Đerđa Ministarstvu inostranih poslova, 25 May 1946

${ }^{4}$ AY, 507/9, 1/1-127-242, Privredni odnosi Jugoslavije i Albanije.

${ }^{5}$ AY, 50-49-569, Albanija.
} 
In November 1946, the Yugoslav government awarded 484 scholarships to young Albanian workers to specialize in various industries. ${ }^{1}$ The Albanian government asked the Yugoslav government to approve the education of its youth in Yugoslav companies and vocational schools, which was accepted by the Yugoslav side. ${ }^{2}$ The conditions were that they knew the Serbian language and that they had completed four grades of high school or elementary school. ${ }^{3}$ According to a report from December 1946, the Committee for Schools and Science of the Government of the Federal People's Republic of Yugoslavia approved scholarships for 96 students from Albania, 27 of whom were already in Yugoslavia. ${ }^{4}$

At the beginning of the new 1947, the entire Albanian press published the results in the reconstruction and construction of the country from the previous year. Bashkimi published an article entitled «The Albanian people have the conditions to move forward towards a better future «, in which, among other things, it emphasized the importance of voluntary work of Albanian youth. The youth road Kuks-Piškopeja, Berat-Čorovode, Bariš-Tepelene and others was designated there. A significant testimony about the construction of the Kuks-Piškopeja road, according to Mitrović, was the diary «NOJ» (People's Youth of Yugoslavia (Narodna omladina Jugoslavije - NOJ). The diary talks about 242 Yugoslav youths elected on the Brčko-Banovići youth railway who went to work in Albania. Mitrović quotes a passage from the diary in his book:

«We woke up and looked in astonishment. We are covered with warm white quilts. They covered us last night, and we didn't even notice. They got up earlier and stared at us. They approached us and told us, but we didn't understand each other, and they would like to explain something to us. Finally, our Shiptars who live in Yugoslavia explained to us that there will be a rally today, a ceremony on the meadow where our camp will be in the future» (Mitrović, 1997, p. 198).

Yugoslav-Albanian youth cooperation continued also in 1947. In Albania, propaganda about that issue had been emphasized through films. In 1947, there were 19 cinemas in Albania. Films that were from Yugoslav production and that were shown in Albania from April to October 1947 were: New Victory, Juliska Krajina, Balkanijada, Youth road, In the Footsteps of the 4th and 5th Offensives, In the Name of the People, Slavica, Strenght and youth. ${ }^{5}$

Albanian youths stayed in Yugoslavia for work and schooling. Many of them were employed as students in the economy in Yugoslav companies. They received 600 dinars and 300 dinars in pocket money in the name of food and

${ }^{1}$ DAMFARS, PA, fol. 2,1946 , doc. no. 10, sign. 14512, Komitet za škole i nauku pri vladi FNRJ Ministarstvu inostranih poslova, 7 December 1946.

${ }^{2}$ DAMFARS, PA, fol. 2, 1946, doc. no. 10, sign. 6293, Školovanje albanskih omladinaca u našim školama i preduzećima, 5 June 1946.

${ }^{3}$ DAMFARS, PA, fol. 2,1946 , doc. no. 10, sign. 6796, Školovanje albanskih omladinaca u našim školama i preduzećima, 13 June 1946.

${ }^{4}$ DAMFARS, PA, fol. 2, 1946, doc. no. 10, sign. 14512, Komitet za škole i nauku pri vladi FNRJ Ministarstvu inostranih poslova, 7 December 1946.

${ }^{5}$ DAMFARS, PA, fol. 1, 1947, doc.no. 1, sign. 420833, Poslanstvo FNRJ Ministarstvu inostranih poslova FNRJ, Povratak Envera Hodže i proslava rođendana, 20 October 1947. 
accommodation in the home. A hundred Yugoslav children stayed in a joint camp with Albanian pioneers, and art troupes were sent to Albania. During 1947, 248 Yugoslav youths visited Albania. ${ }^{1}$ The Ministry of Agriculture of Slovenia reported in January that 20 girls from Albania could be admitted to agricultural-domestic schools. The students would have a free accommodation, food and all other possible expenses in the schools. ${ }^{2}$ Also, in January 1947, the Albanian government applied for another 32 scholarships for its students at Yugoslav universities, but they received an answer from the Yugoslav authorities that they could not recognize their first semester, so it would be best for them to come before the new school year. ${ }^{3}$ Somewhat later, their number was reduced to 20 scholarship holders, because of decline in Yugoslav-Albanian relations. ${ }^{4}$ In July 1947, the Committee for Schools and Science of the Government of the FPRY informed the Albanian government that in the next school year, all Albanian students who would like to study at Yugoslav universities could enroll. On that occasion, the Yugoslav government, for the school year $1947 / 48$, promised about 100 scholarships (hence all old scholarship holders and plus new ones). ${ }^{5}$ There were cases when some Albanian youths behaved inappropriately, so the manager of the dorm in Sušak complained that they were undisciplined and that they wanted to "use the dorm in every way". ${ }^{6}$ Due to complaints about the behavior of some young people, four officials of the Albanian government arrived to visit them. ${ }^{7}$

At the meeting in Tirana on 9 July 1947, the Convention on Cultural Cooperation between Yugoslavia and Albania was signed. It represented a comprehensive coordination of cultural and educational work (scholarships for vocational education, student exchange, courses during the holidays). This meant, above all, investing efforts in higher education institutions, establishing professorial departments, appointing lecturers for language, literature and history in order to get to know the other side. It was also planned to establish a permanent mixed Yugoslav-Albanian commission of 12 members, which was to be divided into two sub-commissions with headquarters in Belgrade and Tirana. ${ }^{8}$

\footnotetext{
1 AY, Fund Ministry of Labor of the Federal People's Republic of Yugoslavia (Ministarstvo rada FNRJ), 25-84-213, Albanski omladinci i radnici u Jugoslaviji.

${ }^{2}$ DAMFARS, PA, fol. 2, 1947, doc. 14, sign. 41833, Šef odseka za stručno obrazovanje Vida Čubrilović Koprivica Ministarstvu inostranih poslova FNRJ, 18 January 1947.

${ }^{3}$ DAMFARS, PA, 1947, fol. 2, doc. 15, sign. 4260, Đerđin telegram Ministarstvu inostranih poslova, 7 January 1947.

${ }^{4}$ DAMFARS, PA, 1947, fol. 2, doc. 15, sign. 41224, Ljubo Osterc Ministarstvu inostranih poslova FNRJ, 21 january 1947.

${ }^{5}$ DAMFARS, PA, 1947, fol. 2, doc. 16, sign. 413934, Komitet za školu i nauku pri Vladi FNRJ Ministarstvu inostranih poslova FNRJ, 24 July 1947.

${ }^{6}$ DAMFARS, PA, 1947, fol. 2, doc. 15, sign. 2717, Upravitelj doma Tomas Ante Glavnoj upravi brodogradnje Sušak, 25 January 1947.

${ }^{7}$ DAMFARS, PA, 1947, fol. 2, doc. 15, sign. 4772, 20 March 1947.

8 DAMFARS, PA, 1947, fol. 2, doc. 15, sign.. 417371, Poslanstvo FNRJ Ministarstvu inostranih poslova FNRJ, Izveštaj o putu predsednika Vlade Albanije, 1 October 1947. About cultural cooperation between Yugoslavia and Albania, see more: Bondžić, 2004, p. 290; Bondžić, 2011; Petrović, 2002, pp. 61-87; Slavković, 2012, pp. 109-128.
} 
A significant example of Yugoslav-Albanian youth work action was the construction of a «youth» railway Durres-Elbasan which was of great importance for traffic communication in Albania. From 6 March 1947, 10,000,000 young people were set aside for the construction of railways, and by 10 October $1947,582,662$ were used. For the railway $25,000,000$ were to be used, and $7,572,730$ for the payment of the debt to the Ministry of Transport for the initial works on the construction of the Durres-Elbasan railway. In March, the first youth brigade left Tirana. The departure was marked solemnly: "A mass of the world gathered in the central square carrying flags, banners and slogans. The trucks that drove the young people were decorated with Albanian and Yugoslav flags and decorated with pictures of Enver and Tito».

The construction of the railway in this way was considered «a school that will educate 12,000 young men and women». During the construction of the railway, courses for illiterate, collective reading groups and discussion groups were planned, as well as the arrival of artistic and sports teams. ${ }^{1}$ The number of participants grew over time, so it amounted to 15,989, of which the youth of Argirokastra was in the lead with 2,606 applicants, and in the area of Kuks, where "women were imprisoned due to fanaticism, 505 young girls applied». ${ }^{2}$ When the works on this railway started, 35 illiteracy courses were established, which were attended by 510 young people, and 132 learned to read and write. Were formed 53 collective reading groups, in which 277 young people participated. ${ }^{3}$

The press regularly followed what was happening on the Durres-Elbasan railway. The arrival of young people continued (working group «Bajram Curi» - 246 young people and 46 girls, working group «Mico Mame» - 275 young people). ${ }^{4} \mathrm{~A}$ competition was organized in April, so «already in the first days of the competition, all work brigades exceeded the norm by an average of $80 \%$, while many young people exceeded it by $350 \% » .^{5}$ The Yugoslav work brigades worked together with the Albanian "with great enthusiasm». The slogans «We work here as in our own country» and «The love of Yugoslav and Albanian youth is boundless» were written on the wagons used by the Yugoslav youth and on the walls of their apartments. ${ }^{6}$ In line with the construction efforts, the Secretariat of the People's Youth of Albania decided to hold weeks 7-15 June declared «Railway Week». ${ }^{7}$

In September, a ten-day competition was organized on the railway in honor of Josip Broz Tito. On that occasion, Liri Beliševa said in her speech: «Our youth railway is rightly called the railway of brotherhood. We love Marshal Tito and his Yugoslavia, because without the help of Marshal Tito and Yugoslavia, we would not be able to win our independence and freedom. (...) Without

\footnotetext{
${ }^{1}$ AY, 112-807-808, 7 March 1947.

${ }^{2}$ AY, 112-807-808, 9 March1947.

${ }^{3}$ AY, 112-809-810, 2 April 1947.

${ }^{4}$ AY, 112-809-810, 4 April 1947.

${ }^{5}$ AY, 112-809-810, 12 April 1947.

${ }^{6}$ AY, 112-812-813, 28 May 1947.

${ }^{7}$ AY, 112-813-814, 6 June 1947.
} 
Tito's help, we would not be able to rebuild the country». ${ }^{1}$ Greeting telegrams were sent to the Yugoslav President: «Dear Marshal, we, the 13,500 young builders of the Durres-Elbasan youth railway, send you our warmest greetings. In close cooperation with Yugoslav technicians and experts, we have achieved great results in our creative work by overcoming all difficulties. As true brothers, we have committed ourselves together to complete a part of the DurresPecin railway, which is $43 \mathrm{~km}$ long, on the day of the Thirtieth anniversary of the Great October Socialist Revolution. From 11 to 21 September, we will work with all our strength, in order to achieve new victories in our work». ${ }^{2}$

In November 1947, on the occasion of the completion of works on this part of the railway, 14,000 railway builders sent a greeting telegram to Enver Hoxha, in which they expressed joy that 35,000 young people, as well as Albanian and Yugoslav experts, achieved a great victory after eight months of uninterrupted work. The telegram further states: «In all competitions and efforts for the construction of the railway, our Yugoslav brothers were constantly with us. We received great and direct help from the people of Yugoslavia, without whom we would not be able to build the railway. Our railroad is the railroad of the brotherhood of our two peoples. We built the railroad, and the railroad built us». ${ }^{3}$ At the opening of the railway on 7 November 1947, albanian minister of the interior, Kochi Dzodze also emphasized Yugoslav assistance and said: «In the construction of the youth railway, we received great material, professional and technical assistance from our ally, the FPRY. This railway is specifically the result of our alliance with Yugoslavia. Albania is lucky to have the FPRY on its borders, which is a great guarantee for our survival and general development». ${ }^{4}$ However, there were numerous difficulties that hindered the progress of the construction of this railway. In order to build a barracks for the Albanian youth, material was given, although it was supposed to be provided by the Albanian government. The material that was sent from Yugoslavia was not unloaded in Durres on time (Dedijer, 1949, p. 185-186). Also, discipline among young people declined, and some whose voluntary work expired had not been replaced, so there was a lack of professional staff. (Gaćeša, 1990, pp. 102-105). ${ }^{5}$ This was also pointed out by the general director of the Railway Construction Company, engineer A. Heibner. In his report in mid-1947, it was mentioned nutrition as a special problem. According to the regulations of the health service, every young person should had received at least 3,800 calories a day, but in fact they received 2,500-3,000 calories. They didn't even have food supplies in the warehouses. In the canteen in Durres, there was not enough food at the administration, many items were missing, especially meat. ${ }^{6}$

${ }^{1}$ AY, 507/9, 1/3-66, Tanjug, 12 September 1947.

${ }^{2}$ AY, 112-819-820, 14 September 1947.

${ }^{3}$ AY, 112-824-825, 1 November 1947. Similar slogans of brotherhood and unity were on the construction of the railway in Yugoslavia, primarily the Brčko-Banovići youth railway, which was opened in November 1946 (Tito, 1947).

${ }^{4}$ AY, 112-824-825, 8 November 1947.

${ }^{5} \mathrm{AY}, 112-820-821,16$ September 1947.

${ }^{6}$ AY, 50-52-320, Izveštaj o celokupnom radu Društva za gradnju železnice, generalni direktor A. Huibner, 29 July 1947. 
The attitude towards Yugoslavia and its help began to change. This was also felt at the level of youth cooperation. In his report on the work in Albania, the advisor at the albanian Ministry of Industry, Zvonko Vugrin, pointed out some disagreements that arose in the cooperation between Yugoslavs and Albanians, and stated that there was talk among the youth: "what should we do for Yugoslavia». ${ }^{1}$

After the new situation in the relations between Yugoslavia and Albania in 1948, there were problems in all fields of cooperation, including youth. The Yugoslav brigade that was on the construction of the Durres-Tirana youth railway left the construction site and returned to the country. In a letter from the Yugoslav brigadiers to the General Council of the People's Youth of Albania, the brigade explained its actions:

«because of the gross insults of the Albanian authorities inflicted on our state leadership, Marshal Tito and our peoples, which are extremely inhumane - our brigade has decided to leave Albania». Albanian brigadiers, who left the construction of the Belgrade-Zagreb highway a month earlier, did the same, citing as a cause "the difficult situation in which the youth and peoples of Yugoslavia are involved» (Mitrović, 1997, p. 200-201).

Finally, it should be pointed out that the youth cooperation between Yugoslavia and Albania developed in accordance with the good relations between the two countries. It was paid attention by the party leadership and the youth leaders supported political and any other type of cooperation. It was propagated through Yugoslav-produced films, which were shown in Albania, by the stay of Yugoslav youth in Albania, by learning the languages, by opening Yugoslav bookstores in Albania. It included the cooperation of youth organizations, the organization of joint youth congresses, the specialization of Albanian young workers in Yugoslav factories, the education of Albanian students in Yugoslav schools, and the study of Albanian students at Yugoslav faculties. A special segment of the collaboration was youth voluntary work actions, in which Albanian young workers, following the example of Yugoslavs, helped rebuild their country. Also, Yugoslav youths worked on the railways in Albania. A particularly important example was the construction of the Durres-Elbasan "youth railway», which emphasized the unity of the two countries. The intensity of youth cooperation decreased in line with the decline of Yugoslav-Albanian relations, which collapsed after Albanian support for the Informbiro resolution and the cessation of all forms of cooperation between the two countries.

\section{References}

Adamović, V. (1987). Enver Hoxha: mehanizmi vlasti. (Enver Hoxha: the mechanism of power). Ideje: jugoslovenski studentski časopis, 5-6, 162-171. [in Serbian].

Archive of Yugoslavia (Belgrade, Serbia), Fund 25 - Ministry of Labor of the Federal People's Republic of Yugoslavia (Ministarstvo rada FNRJ); Fund 50- Presidency of the Government of the Federal People's Republic of Yugoslavia (Predsedništvo Vlade FNRJ); Fund 112 - Tanjug

${ }^{1} \mathrm{AY}, 507 / 9,1 / 1-127-242,1$ August 1947. 
news agency (Novinska agencija Tanjug), Fund 507/9 - Commission for International Relations of the Central Committee of the SKJ (Komisija za međunarodne veze CK SKJ), Fund 836 - Office of the Marshal of Yugoslavia (Kancelarija Maršala Jugoslavije).

Avramov, S. (1985). Savezi u politici Narodne Socijalističke Republike Albanije. (Alliances in the politics of the People 's Socialist Republic of Albania). Marksistička misao: časopis za teoriju i praksu socijalizma i socijalističkog samopupravljanja, 3, 170-194. [in Serbian].

Babić, M. (1981). Enver Hodžina Albanija. (Enver Hoxha Albania). Beograd: Novinska agencija Tanjug. [in Serbian].

Balčevski, M. (1987). Albanija po Enver Hoxha. (Albania with Enver Hoxha). Skopje: Makedonska kniga. [in Macedonian].

Bondžić, D. (2004). Beogradski univerzitet 1944-1952. (University of Belgrade 1944-1952). Beograd: Institut za savremenu istoriju. [in Serbian].

Bondžić, D. (2011). Misao bez pasoša: međunarodna saradnja Beogradskog univerziteta 19451960. (Thought without a passport: international cooperation of the University of Belgrade 1945-1960). Beograd: Institut za savremenu istoriju. [in Serbian].

Borozan, Đ. (1995). Velika Albanija-porijeklo, ideje, praksa. (Greater Albania-origin, ideas, practice). Beograd: Vojnoistorijski institut Vojske Jugoslavije.[in Serbian].

Borozan, Đ. (1997). Paternalistička ponašanja albanskih vlada prema Albancima u Jugoslaviji tokom 20. vijeka. (Paternalistic attitudes of Albanian governments towards Albanians in Yugoslavia during the 20th century).Vojno delo, 2, 28-40. [in Bosnian].

Borozan, Đ. (1999). Albanija u kampanji Kominforma protiv Jugoslavije 1948-1950.(Albania in the Cominform campaign against Yugoslavia 1948-1950). In: Kačavenda, P. (Ed.) Jugoslovensko-sovjetski sukob 1948. Godine (pp. 49-58). Beograd: Institut za savremenu istoriju. [in Croatian].

Borozan, Đ. (2005). Jugoslovensko-albanski odnosi u prvoj deceniji Hladnog rata. (YugoslavAlbanian relations in the first decade of the Cold War). In: Dimić, Lj. (Ed.). Velike sile i male države u Hladnom ratu 1945-1955, Slučaj Jugoslavije, (pp.131-139). Beograd: Filozofski fakultet, Katedra za istoriju Jugoslavije, Arhiv Srbije i Crne Gore, Institut za noviju istoriju Srbije, London: Centar za istraživanja hladnog rata LST. [in Serbian].

Broz Tito, J. (1947). Graditeljima omladinske pruge. (To the builders of the youth railroad). Beograd: Novo pokoljenje. [in Croatian].

Cvetković, V. (2012). Diplomatske misije FNRJ u Sofiji, Bukureštu i Tirani 1953-1954: povratak ambasadora, uslovi rada i incidenti. (Diplomatic missions of the Federal People's Republic of Yugoslavia in Sofia, Bucharest and Tirana 1953-1954: return of ambassadors, working conditions and incidents). In: Selinić, S. (Ed.). Jugoslovenska diplomatija 1945-1961, (pp. 205-220). Beograd: Institut za noviju istoriju Srbije. [in Serbian].

Cvetković, V. (2013). Pogled iza gvozdene zavese: jugoslovesnka politika prema zemljama narodne demokratije u susedstvu 1953-1958. (A Look Behind the Iron Curtain: Yugoslav Policy Towards the Neighborhood People's Democracy Countries 1953-1958). Beograd: Institut za noviju istoriju Srbije. [in Bosnian].

Dedijer, V. (1949). Jugoslovensko-albanski odnosi: 1939-1948. (Yugoslav-Albanian relations: 1939-1948).Beograd: Borba. [in Serbian].

Dervishi, K. (2012). Kryeministrat dhe ministrat e shtetit shqiptar në 100 vjet. (The prime ministers and ministers of the Albanian state in 100 years). Tiranë: Shtëpia Botuese «55«. [in Albanian].

Dervishi, K. (2016). Lëvizja Komuniste në vitet 1924-1944 dhe formimi i PKSH-së. (The Communist Movement in 1924-1944 and the formation of the SNP). Tiranë: Shtëpia Botuese «55». [in Albanian].

Dimić, Lj. (Ed.) (2010). Jugoslovensko-sovjetski odnosi: 1945-1956. (Yugoslav-Soviet relations: 1945-1956.) Beograd: Ministarstvo spoljnih poslova. [in Serbian].

Diplomatic Archive of the Ministry of Foreign Affairs of the Republic of Serbia (Belgrade) Political Archives, 1945-1948, Albania.

Elsie, R. (2013). A biographical dictionary of Albanian history. London: I. B. Tauris.

Fevziu, B. (2014). Enver Hoxha: prva biografija zasnovana na dokumenti od ličnata arhiva $i$ na ispovedite na onie što go poznavaa. (Enver Hoxha: the first biography based on documents from his personal archive and the confessions of those he knew). Skopje: Fondacija Otvoreno opštestvo - Makedonija. [in Serbian]. 
Fevziu, B. (2011). Enver Hoxha. Tiranë: UET Press \& Klan.

Fowkes, B. (2000). Eastern Europe 1945-1969. From Stalinism to Stagnation. Harlow [etc.]: Longman.

Frasheri, K. (1964). The History of Albania. A Brief Survey. Tirana.

Gaćeša, Nikola L. (1990). Privredni odnosi Jugoslavije i Albanije 1945-1948. (Economic relations between Yugoslavia and Albania 1945-1948). Zbornik Matice srpske za istoriju, 42, 87-127. [in Croatian].

Hoxha, E. (1979). Avec Staline: souvenirs. (With Stalin: memories). Tirana: 8. Nëntori. [in French].

Hoxha, E. (1982). Titoisti. (Supporters of Tito). Tirana: Izdavačka kuća «8 nentori«.[in Serbian].

Jugoslavija - trideset godina posle oslobođenja i pobede na fašizmom 1945-1975. (Yugoslavia thirty years after the liberation and victory over fascism 1945-1975). (1975). Beograd: Savezni zavod za statistiku. [in Croatian].

Kidrič, B. (1960). Podaci reparacione komisije potvrđuju nepravdu koja se čini Jugoslaviji u pogledu reparacija, Sabrana dela. (The data of the reparations commission confirm the injustice that seems to Yugoslavia in terms of reparations), Collected Works III. Beograd: Komunist. [in Serbian].

Komatina, M. (1995). Enver Hoxha i jugoslovensko-albanski odnosi. (Enver Hoxha and YugoslavAlbanian Relations). Beograd: Službeni list. [in Serbian].

Kongres SKOJ-a i Narodne omladine Jugoslavije. (Congress of SKOJ and the People's Youth of Yugoslavia). (1949). Beograd: Centralni komitet Narodne omladine Jugoslavije. [in Serbian].

Krempton, R. (2003). Balkan posle Drugog svetskog rata. (The Balkans after World War II). Beograd: Clio. [in Bosnian].

Laker, V. (1999). Istorija Evrope 1945-1992. (History of Europe 1945-1992). Beograd: Clio. [in Bosnian].

Mijalković, S., \& Brajović, A. (1980). Gosti socijalističke Jugoslavije 1944-1980. (Guests of socialist Yugoslavia 1944-1980). Beograd: Privredna štampa. [in Bosnian].

Milošević, S. (2015). Promene u agrarnoj strukturi izazvane raseljavanjem stanovništva na prostoru Jugoslavije u toku Drugog svetskog rata. (Changes in the agrarian structure caused by the displacement of the population in Yugoslavia during the Second World War.) In: Jovanović, V. (Ed.). Tradicija i transformacija: političke i društvene promene u Srbiji $i$ Jugoslaviji u 20.veku, I (pp. 253-279). Beograd: Institut za noviju istoriju Srbije. [in Bosnian].

Mitrović, M. (1988). Društveno-ekonomske promene u Srbiji I organizacija upravljanja privredom 1944-1952. (Socio-economic changes in Serbia and the organization of economic management 1944-1952). Beograd: Institut za istoriju radničkog pokreta Srbije; Požarevac: Centar za kulturu, Edicija «Braničevo». [in Bosnian].

Mitrović, M. (1997). Izgubljene iluzije: prilozi za društvenu istoriju Srbije 1944-1952. (Lost illusions: contributions to the social history of Serbia 1944-1952). Beograd: Institut za noviju istoriju Srbije. [in Bosnian].

Mugoša, D. (1975). Na zadatku. (On a mission). Beograd: Četvrti jul. [in Croatian].

Petranović, B. (1964). Izgradnja socijalizma u Jugoslaviji 1945-1963. (Building socialism in Yugoslavia 1945-1963). Beograd: Radnički Univerzitet «Đuro Salaj «. [in Bosnian].

Petranović, B. (1988). Istorija Jugoslavije 1918-1988. (History of Yugoslavia 1918-1988), III. Beograd: Nolit. [in Bosnian].

Petranović, B. (1994). Jugoslavija, velike sile i balkanske zemlje 1945-1948: Iskustvo «narodne demokratije «kao partijske države. (Yugoslavia, the Great Powers and the Balkan Countries 1945-1948: The Experience of «People's Democracy» as a Party State). Beograd, Podgorica: Istorijski institut Crne Gore. [in Bosnian].

Petranović, B. (Ed.) (1995). Zapisnici sa sednica Politbiroa CK KPJ (11. jun 1945-7. jul 1948). (Minutes from the sessions of the Politburo of the CPY Central Committee (June 11, 1945 July 7, 1948)). Beograd: Arhiv Jugoslavije, Službeni list SRJ. [in Bosnian].

Petrović, Lj. (2002). Kulturne veze Jugoslavije i Albanije 1946-1948. (Cultural ties between Yugoslavia and Albania 1946-1948). Istorija 20 veka, 2, 61-87. [in Bosnian].

Pipa, A. (1990). Albanian Stalinism. Ideo-Political Aspects. New York: Columbia university press. Pollo, S. \& Puto, A. (1974). Histoire de l'Albanie: des origines a nos jours. (History of Albania: from its origins to the present day). Roanne: Editions Horvath. [in French]. 
Selinić, S. \& Bajagić, D. (2010). Jugoslavija i svet 1945-1950. Hronologija. (Yugoslavia and the World 1945-1950. Chronology). Beograd: Institut za noviju istoriju Srbije. [in Bosnian].

Slavković, B. (2012). Jugoslovensko-albanska saradnja u oblasti kulture, nauke i prosvete 19451948. (Yugoslav-Albanian cooperation in the field of culture, science and education 19451948). Istorija 20. veka, 3, 109-128. [in Serbian].

Smodlaka, J. (1986). Partizanski dnevnik. (Partisan diary). Zagreb: Spektar. [in Bosnian].

Stojković, M. (Ed.) (1998). Balkanski ugovorni odnosi: 1876-1996: dvostrani $i$ višestrani međunarodni ugovori $i$ drugi diplomatski akti o državnim granicama, političkoj i vojnoj saradnji, verskim i etničkim manjinama (1919-1945). (Balkan Contractual Relations: 1876-1996: bilateral and multilateral international agreements and other diplomatic acts on state borders, political and military cooperation, religious and ethnic minorities (1919-1945)). Beograd: Službeni list SRJ : Međunarodna politika. [in Serbo-Croatian].

Љuljagić, B. (2019). Odnos jugoslovenskoga i albanskog komunističkog vrha od kraja Drugoga svjetskog rata do prekida odnosa (1945-1948). (The relationship between the Yugoslav and Albanian communist leaders from the end of the Second World War to the severance of relations (1945-1948). Časopis za suvremenu povjest, 1, 213-231. [in Croatian].

Vasfi, B. (2012). Enver Hoxha nё optikë të re. (Enver Hoxha in new optics). Tiranë: Shtлpia Botuese Uegen. [in Albanian].

Vikers, M. \& Petifer, J. (1998). Albanija — od anarhije do balkanskog identiteta. (Albania from anarchy to Balkan identity). Beograd: NEA. [in Serbian].

Zlatar, P. (1986). Enver Hoxha: politička biografija. (Enver Hoxha: A Political Biography). Beograd: Rad. [in Serbo-Croatian].

Živković, D. (ed.) (1980). Hronologija radničkog pokreta i SKJ 1919-1979. (Chronology of the workers' movement and the SKJ 1919-1979), III. Beograd: Narodna knjiga, Institut za savremenu istoriju. [in Bosnian].

Živković, N. (1996). Stanje u jugoslovenskoj privredi neposredno po završetku Drugog svetskog rata. (The situation in the Yugoslav economy immediately after the end of the Second World War). In: Kačavenda, P. (Ed.). Balkan posle Drugog svetskog rata (pp. 51-55). Beograd: Institut za savremenu istoriju. [in Bosnian].

\section{Список використаної літератури}

Adamović V. Enver Hoxha: mehanizmi vlasti. Ideje: jugoslovenski studentski časopis. 1987. No56. P. 162-171.

Archive of Yugoslavia (Belgrade, Serbia), Fund 25 - Ministry of Labor of the Federal People's Republic of Yugoslavia (Ministarstvo rada FNRJ); Fund 50- Presidency of the Government of the Federal People's Republic of Yugoslavia (Predsedništvo Vlade FNRJ); Fund 112 Tanjug news agency (Novinska agencija Tanjug), Fund 507/9 - Commission for International Relations of the Central Committee of the SKJ (Komisija za međunarodne veze CK SKJ), Fund 836 - Office of the Marshal of Yugoslavia (Kancelarija Maršala Jugoslavije).

Avramov S. Savezi u politici Narodne Socijalističke Republike Albanije. Marksistička misao: časopis za teoriju i praksu socijalizma i socijalističkog samopupravljanja. 1985. No 3. P. 170194.

Babić M. Enver Hodžina Albanija. Beograd: Novinska agencija Tanjug, 1981. 266 s.

Balčevski M. Albanija po Enver Hoxha. Skopje: Makedonska kniga. 1987. 299 s.

Bondžić, D. Beogradski univerzitet 1944-1952. Beograd: Institut za savremenu istoriju, 2004. $400 \mathrm{~s}$.

Bondžić D. Misao bez pasoša: međunarodna saradnja Beogradskog univerziteta 1945-1960. Beograd: Institut za savremenu istoriju, 2011. $358 \mathrm{~s}$.

Borozan Đ. Velika Albanija-porijeklo, ideje, praksa. Beograd: Vojnoistorijski institut Vojske Jugoslavije, 1995. $571 \mathrm{~s}$.

Borozan Đ. Paternalistička ponašanja albanskih vlada prema Albancima u Jugoslaviji tokom 20. vijeka. Vojno delo. 1997. No2. P. 28-40.

Borozan Đ. Albanija u kampanji Kominforma protiv Jugoslavije 1948-1950. Kačavenda, P. (Ed.) Jugoslovensko-sovjetski sukob 1948. Godine. Beograd: Institut za savremenu istoriju, 1999. P. 49-58. 
Borozan Đ. Jugoslovensko-albanski odnosi u prvoj deceniji Hladnog rata. Dimić Lj. (Ed.). Velike sile i male države u Hladnom ratu 1945-1955, Slučaj Jugoslavije. Beograd: Filozofski fakultet, Katedra za istoriju Jugoslavije, Arhiv Srbije i Crne Gore, Institut za noviju istoriju Srbije, London: Centar za istraživanja hladnog rata LST, 2005. P. 131-139.

Broz Tito J. Graditeljima omladinske pruge. Beograd: Novo pokoljenje, 1947. 132 s.

Cvetković V. Diplomatske misije FNRJ u Sofiji, Bukureštu i Tirani 1953-1954: povratak ambasadora, uslovi rada i incidenti. Selinić, S. (Ed.). Jugoslovenska diplomatija 1945-1961. Beograd: Institut za noviju istoriju Srbije, 2012. P. 205-220.

Cvetković V. Pogled iza gvozdene zavese: jugoslovesnka politika prema zemljama narodne demokratije u susedstvu 1953-1958. Beograd: Institut za noviju istoriju Srbije. 2013. $513 \mathrm{~s}$.

Dedijer V. Jugoslovensko-albanski odnosi: 1939-1948. Beograd: Borba, 1949. $225 \mathrm{~s}$.

$273 \mathrm{~s}$.

Dervishi K. Lëvizja Komuniste në vitet 1924-1944 dhe formimi i PKSH-së. Tiranë: Shtëpia Botuese «55», 2016. $292 \mathrm{~s}$.

Dimić Lj. (Ed.) Jugoslovensko-sovjetski odnosi: 1945-1956. Beograd: Ministarstvo spoljnih poslova, 2010. $1006 \mathrm{~s}$.

Diplomatic Archive of the Ministry of Foreign Affairs of the Republic of Serbia (Belgrade) Political Archives, 1945-1948, Albania.

Elsie R. A biographical dictionary of Albanian history. London: I. B. Tauris, 2013. $541 \mathrm{~s}$.

Fevziu B. Enver Hoxha: prva biografija zasnovana na dokumenti od ličnata arhiva i na ispovedite na onie što go poznavaa. Skopje: Fondacija Otvoreno opštestvo - Makedonija, 2014. $406 \mathrm{~s}$.

Fevziu B. Enver Hoxha. Tiranë: UET Press \& Klan, 2011.232 s.

Fowkes B. Eastern Europe 1945-1969. From Stalinism to Stagnation. Harlow [etc.]: Longman, 2000. $190 \mathrm{p}$.

Frasheri K. The History of Albania. A Brief Survey. Tirana, 1964. 344 p.

Gaćeša Nikola L. Privredni odnosi Jugoslavije i Albanije 1945-1948. Zbornik Matice srpske za istoriju. 1990. No42. P. 87-127.

Hoxha E. Avec Staline: souvenirs. Tirana: 8. Nëntori, 1979. 224 p.

Hoxha E. Titoisti. Tirana: Izdavačka kuća «8 nentori». 1982. 691 p.

Jugoslavija - trideset godina posle oslobođenja i pobede na fašizmom 1945-1975. Beograd: Savezni zavod za statistiku, 1975. $132 \mathrm{~s}$.

Kidrič B. Podaci reparacione komisije potvrđuju nepravdu koja se čini Jugoslaviji u pogledu reparacija, Sabrana dela, III. Beograd: Komunist, 1960. $58 \mathrm{~s}$.

Komatina M. Enver Hoxha i jugoslovensko-albanski odnosi. Beograd: Službeni list. 154 s.

Kongres SKOJ-a i Narodne omladine Jugoslavije. (1949). Beograd: Centralni komitet Narodne omladine Jugoslavije, 1995. $213 \mathrm{~s}$.

Krempton R. Balkan posle Drugog svetskog rata. Beograd: Clio, 2003. $510 \mathrm{~s}$.

Laker V. Istorija Evrope 1945-1992. Beograd: Clio, 1999. $721 \mathrm{s.}$

Mijalković, S., Brajović, A. Gosti socijalističke Jugoslavije 1944-1980. Beograd: Privredna štampa, 1980. $655 \mathrm{~s}$.

Milošević S. Promene u agrarnoj strukturi izazvane raseljavanjem stanovništva na prostoru Jugoslavije u toku Drugog svetskog rata. Jovanović, V. (Ed.). Tradicija i transformacija: političke $i$ društvene promene u Srbiji i Jugoslaviji u 20.veku, I. Beograd: Institut za noviju istoriju Srbije, 2015. P. 253-279.

Mitrović M. Izgubljene iluzije: prilozi za društvenu istoriju Srbije 1944-1952. Beograd: Institut za noviju istoriju Srbije, 1977. $307 \mathrm{~s}$.

Mitrović M. Društveno-ekonomske promene u Srbiji I organizacija upravljanja privredom 19441952. Beograd: Institut za istoriju radničkog pokreta Srbije; Požarevac: Centar za kulturu, Edicija «Braničevo», 1988. $314 \mathrm{~s}$.

Mugoša D. Na zadatku. Beograd: Četvrti jul, 1975. $311 \mathrm{~s}$.

Petranović B. Istorija Jugoslavije 1918-1988, III. Beograd: Nolit, 1988. $431 \mathrm{~s}$.

Petranović B. Izgradnja socijalizma u Jugoslaviji 1945-1963. Beograd: Radnički Univerzitet «Đuro Salaj», 1964. $265 \mathrm{~s}$.

Petranović B. Jugoslavija, velike sile i balkanske zemlje 1945-1948: Iskustvo «narodne demokratije» kao partijske države. Beograd; Podgorica: Istorijski institut Crne Gore, 1994. 89 s.

Petranović B. (Ed.) Zapisnici sa sednica Politbiroa CK KPJ (11 jun $1945-7$ jul 1948). Beograd: Arhiv Jugoslavije, Službeni list SRJ, 1995. 74 s. 
Petrović Lj. Kulturne veze Jugoslavije i Albanije 1946-1948. Istorija 20. veka. 2002. No 2. P. 61-87.

Pipa A. Albanian Stalinism. Ideo-Political Aspects. New York: Columbia university press, 1990. $291 \mathrm{p}$.

Pollo S.,Puto A. Histoire de l'Albanie: des origines a nos jours. Roanne: Editions Horvath, 1974. $241 \mathrm{~s}$.

Selinić S., Bajagić D. Jugoslavija i svet 1945-1950. Hronologija. Beograd: Institut za noviju istoriju Srbije, 2010. $483 \mathrm{~s}$.

Slavković B. Jugoslovensko-albanska saradnja u oblasti kulture, nauke i prosvete 1945-1948. Istorija 20. veka. 2012. No3. P. 109-128.

Smodlaka J. Partizanski dnevnik. Zagreb: Spektar, 1986. 242 s.

Stojković M. (Ed.) Balkanski ugovorni odnosi: 1876-1996: dvostrani i višestrani međunarodni ugovori i drugi diplomatski akti o državnim granicama, političkoj i vojnoj saradnji, verskim i etničkim manjinama (1919-1945). Beograd: Službeni list SRJ: Međunarodna politika, 1998. $581 \mathrm{p}$.

Šuljagić B. Odnos jugoslovenskoga i albanskog komunističkog vrha od kraja Drugoga svjetskog rata do prekida odnosa (1945-1948). Časopis za suvremenu povjest. 2019. No1. P. 213-231.

Vasfi B. Enver Hoxha në optikë të re. Tiranë: Shtлpia Botuese Uegen, 2012. 316 s.

Vikers M., Petifer J. Albanija — od anarhije do balkanskog identiteta. Beograd: NEA, 1998. $309 \mathrm{~s}$.

Zlatar P. Enver Hoxha: politička biografija. Beograd: Rad, 1986. 392 p.

Živković D. (ed.) Hronologija radničkog pokreta i SKJ 1919-1979, III. Beograd: Narodna knjiga, Institut za savremenu istoriju, 1980. $479 \mathrm{~s}$.

Živković N. Stanje u jugoslovenskoj privredi neposredno po završetku Drugog svetskog rata. Kačavenda, P. (Ed.). Balkan posle Drugog svetskog rata. Beograd: Institut za savremenu istoriju, 1996. P. 51-55.

Стаття надійшла до редакиї 28.06.2020

\author{
Славкович Мирич Божиця \\ Інститут новітньої історії Сербії \\ вул. Ніколе Пасіка 11, Белград, 11000, Республіка Сербія
}

\title{
СПІВПРАЦЯ МІЖ ЮГОСЛАВСЬКОЮ ТА АЛБАНСЬКОЮ МОЛОДДЮ В ПЕРІОД 1945-1948 РОКІВ
}

\section{Резюме}

Після закінчення Другої світової війни Югославія і Албанія почали активно співпрацювати. Підписанням Угоди про дружбу в 1946 році між двома країнами досягли високого рівня співпраці в політичній, культурній, медичній, військовій сферах. Але вже через рік - в середині 1947 р. - почалася криза в югославськоалбанських відносинах. Вона була пов'язана з візитом Енвера Ходжі в Москву, в результаті якого радянське і албанське керівництво стало безпосередньо співпрацювати. Як тільки прийняли Резолюцію Інформбюро, Албанія виступила на iї підтримку і в країні забули про югославську допомогу і двосторонню співпрацю. Нормалізація відносин між Югославією та Албанією сталася після 1955 року. Співпраця та югославської і албанської молоді є одним з позитивних аспектів відносин між двома країнами після Другої світової війни. Молодіжна організація BRASH в Албанії була створена за моделлю ОСАМЮ (Об'єднаний союз антифашистської молоді Югославії). Наслідуючи приклад Югославії, вони брали участь у волонтерській діяльності, а також у відновленні країни. Одним із прикладів співпраці між югославською і албанською молоддю є будівництво залізниці Дуррес - Ельбасан. Відповідно до спеціального протоколу від листопада 1946 року 
югославський уряд погодився прийняти до себе кілька молодих людей з Албанії і організував підготовку цих кадрів для роботи в ключових галузях економіки. Так, з 1946 по 1948 р. в Югославію прибули 730 молодих людей, в 1946 році - 389, в 1947 році - 188 і в 1948 р - 153. На прохання уряду Албанії вони вчилися в професійних училищах, технікумах з гірничої справи, транспорту, сільського господарства, а також проходили навчання за різними напрямами, спеціальностями і галузям: економіка, текстильна, металообробна, графічна, електротехнічна промисловість та ін. Крім того, в югославських університетах навчалися близько 450 албанських студентів, більше половини з яких були стипендіатами югославського уряду. Однак розрив югославсько-албанських відносин, який почався в середині 1947 року й досяг критичних масштабів в 1948 році, також вплинув на цей аспект співпраці - югославська і албанська молодь повернулася додому, і таким чином співпрацю було перервано.

Ключові слова: Албанія, співробітництво, молодь, молодіжна політика, Югославія, період після Другої світової війни.

\section{Славкович Мирич Божица}

Институт новейшей истории Сербии

ул. Николе Пасека 11 Белград, 11000, Республика Сербия

\section{СОТРУДНИЧЕСТВО МЕЖДУ ЮГОСЛАВСКОЙ И АЛБАНСКОЙ МОЛОДЕЖЬЮ В ПЕРИОД 1945-1948 ГОДОВ}

\section{Резюме}

После окончания Второй мировой войны Югославия и Албания начали активно сотрудничать. Подписанием Соглашения о дружбе в 1946 году две страны достигли высокого уровня сотрудничества в политической, культурной, медицинской, военной сферах. Но уже год спустя - в середине 1947 г. - начался кризис в югославско-албанских отношениях. Он был связан с визитом Энвера Ходжи в Москву, в результате которого советское и албанское руководство стало непосредственно сотрудничать. Как только приняли Резолюцию Информбюро, Албания выступила в ее поддержку и в стране забыли про югославскую помощь и двустороннее сотрудничество. Нормализация отношений между Югославией и Албанией произошла после 1955 года. Сотрудничество между югославской и албанской молодежью являлось одним из положительных аспектов отношений между двумя странами после Второй мировой войны. Молодежная организация BRASH в Албании была создана по модели ОСАМЮ (Объединённый союз антифашистской молодежи Югославии). Следуя примеру Югославии, они принимали участие в волонтерской деятельности, а также в восстановлении страны. Одним из примеров сотрудничества между югославской и албанской молодежью являлось строительство железной дороги Дуррес - Эльбасан. В соответствии со специальным протоколом от ноября 1946 года югославское правительство согласилось принять к себе определенное число молодых людей из Албании и организовало подготовку этих кадров для работы в ключевых отраслях экономики. Так, с 1946 по 1948 г. в Югославию прибыли 730 молодых людей в 1946 году - 389, в 1947 году - 188 и в 1948 г. - 153. По просьбе правительства Албании они учились в профессиональных училищах, техникумах горного дела, транспорта, сельского хозяйства, а также проходили обучение по разным направлениям, специальностям и отраслям: экономике, текстильной, металлообрабатывающей, графической, электротехнической промышленности и др. Кроме того, в югославских университетах учились около 450 албанских студентов, более по- 
ловины из которых являлись стипендиатами югославского правительства. Однако разрыв югославско-албанских отношений, который начался в середине 1947 года и достиг критических масштабов в 1948 году, также повлиял на этот аспект сотрудничества - югославская и албанская молодежь вернулась домой, и таким образом сотрудничество было прервано.

Ключевые слова: Албания, сотрудничество, молодежь, Югославия, период после Второй мировой войны. 